\title{
Studies on persistent organic pollutants residue in water, sediment and fish tissues of River Sutlej, India
}

\begin{tabular}{l}
\hline Paper received: 06.12.2017 \\
\hline \\
Authors Info \\
N. Kaur', P. Singh" ${ }^{1 *}$, J.S. Bedi ${ }^{2}$ \\
and A. Gupta \\
'Department of Fisheries Resource \\
Management, College of fisheries, \\
Guru Angad Dev Veterinary and \\
Animal Sciences University, \\
Ludhiana-141 004, India \\
${ }^{2}$ School of Veterinary Public Health \\
and Zoonosis, Guru Angad Dev \\
Veterinary and Animal Sciences \\
University, Ludhiana-141 004, India \\
${ }^{3}$ Farming System Research Centre, \\
Sher-e-Kashmir University of \\
Agricultural Sciences and \\
Technology, Jammu-180 009, \\
Jammu and Kashmir
\end{tabular}

\section{Edited by \\ Dr. V. K. Tiwari}

Reviewed by

Dr. Ravindra Khaiwal

Dr. R. B. Raizada

\section{Abstract}

Aim: To study the level of persistent organic pollutants in the environment of River Sutlej and rule out its detrimental effects on aquatic fauna.

Methodology: Two different sites were selected for the study, one was before the confluence of a polluted tributary (Site I) another was after the confluence of polluted tributary (Site II). Analysis of water, sediment, gills and muscles of selected fish species was done to detect the level of persistent organic pollutants using Gas Chromatography.

Results: Among POP's, PCB-28 was detected during monsoon period $\left(0.55 \mathrm{ng} \mathrm{ul}^{-1}\right)$ at Site I, while as it was detected both during monsoon $\left(0.65 \mathrm{ng} \mathrm{ul}^{-1}\right)$ and post-monsoon $\left(0.49 \mathrm{ng} \mathrm{ul}^{-1}\right)$ period at Site $\mathrm{Il}$ in the water samples. Similarly, PCB-28 was detected in gills of Cirrhinus mrigala during pre $\left(0.26 \mathrm{ng} \mathrm{g}^{-1}\right)$ and postmonsoon $\left(0.27 \mathrm{ng} \mathrm{g}^{-1}\right)$ periods at Site I, while at Site II it was detected only during monsoon period $\left(0.17 \mathrm{ng} \mathrm{g}^{-1}\right)$. In Aoricthysaor gills, only PCB-28 was detected during pre-monsoon ( $\left.0.34 \mathrm{ng} \mathrm{g}^{-1}\right)$ and monsoon periods $(0.19$ $\left.\mathrm{ng} \mathrm{g}^{-1}\right)$ at Site II. In Heteropneustes fossilis PCB-28 was detected during pre-monsoon period $\left(0.26 \mathrm{ng} \mathrm{g}^{-1}\right)$ at Site I, while at Site II it was found during pre-monsoon $\left(0.21 \mathrm{ng} \mathrm{g}^{-1}\right)$ and monsoon $\left(0.17 \mathrm{ng} \mathrm{g}^{-1}\right)$ periods. In Catla Catla gill samples among PCB's only PCB-28 was detected during pre-monsoon ( $\left.0.32 \mathrm{ng} \mathrm{g}^{-1}\right)$, monsoon ( 0.29 $\left.\mathrm{ng} \mathrm{g}^{-1}\right)$ and post-monsoon periods $\left(0.24 \mathrm{ng} \mathrm{g}^{-1}\right)$ at Site II while Mirex $\left(0.01 \mathrm{ng} \mathrm{g}^{-1}\right)$ was detected at Site I during post-monsoon period.

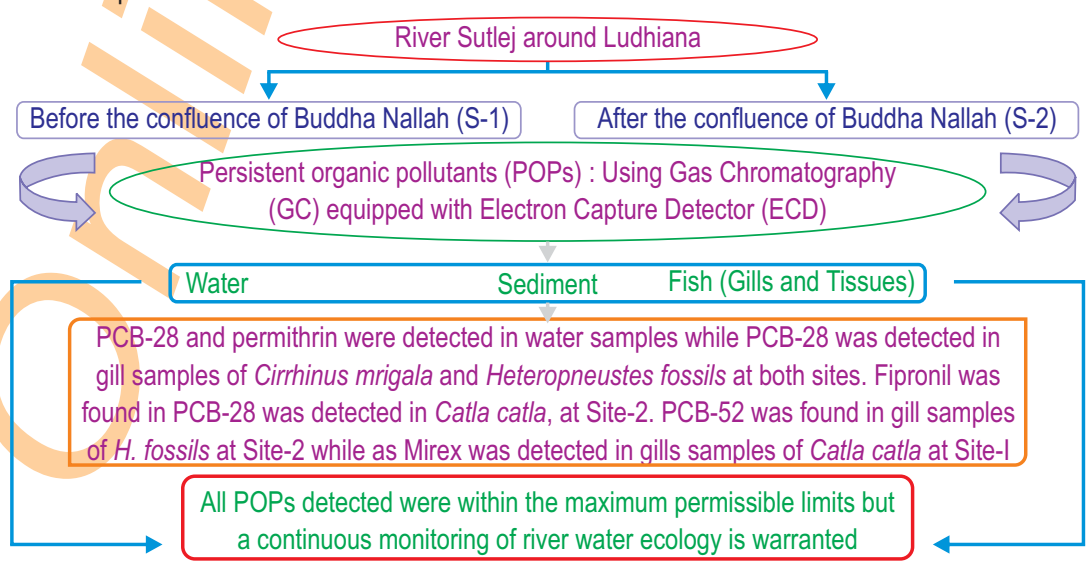

Interpretation: The study concluded that continuous monitoring of pesticide residue is warranted in the river Sutlej to rule out any detrimental effect of pesticide pollution on aquatic fauna.

Keywords: Buddha Nallah, Fish tissues, Organic pollutants, River Sutlej,

How to cite : Kaur, N., P. Singh, J.S. Bedi and A. Gupta: Studies on persistent organic pollutants residue in water, sediment and fish tissues of River Sutlej, India. J. Environ. Biol., 40, 258-264 (2019). 


\section{Introduction}

The aquatic resources are being used as a dumping ground for various wastes, right from the birth of human civilization. This is being done with the idea that aquatic resources have a vast water column and whatever is dumped in it becomes non-toxic over a period of time (Hynes, 1960). In India about $70 \%$ of the rivers are polluted, due to fast industrialization and urbanization as majority of rivers are being used as dumping grounds (Brraich and Jangu, 2013).

The River Sutlej which has been always considered as one of the major sources of capture fisheries in India has now become a deleterious sewer due to random and excessive pouring of industrial wastes into it, thus posing a threat to aquatic life (Garg et al., 2009).

Pesticides become a major cause of concern to aquatic environment because of their property to persist, toxicity and tendency of bio-accumulation over a period of time. (Joseph and Raj, 2010).The pesticides are posing a big threat to the protein rich fish biodiversity of the aquatic environment (Sharma and Singh, 2007). Pesticides at chronic levels can cause diverse effects on fish including oxidative damage to tissues, inhibition of acetylcholinesterase activity, histopathological alterations and mutagenic changes (Banee et al., 2009). Besides, this pathological alterations occur in many vital organs like liver, blood vessels, kidneys and gills. The alterations in liver cells include changes like cytoplasmic granulation, dis-orientation of liver plate and shrinkage of liver mass cells. The changes in kidneys are also prominent which include changes in glomeruli, cytoplasmic vacuolization and cell atrophy. Pesticides like methoxychlor cause pathological changes in blood vessels leading to blue gill disease (Murthy et al., 2013).

Persistent organic pollutants (PoPs) form a major group due to their hazardous nature and ability to bioaccumulate, persist and transport to long distance (Ntow, 2001). During the recent years there has been a growing interest among the researchers to study these chemicals due to their toxic potentiality and adverse effects on human beings (Sethi and Bhattacharya, 1999). Due to this growing concern the Stockhlm convention on PoPs was held in 2001. This convention has recommended banning of around nine organochlorine pesticides (OCPs) and three industrial chemicals or byproducts. But despite all these measures, these chemicals are still in use in some developing countries owing to low cost and versatility in industry, agriculture and public health (Tanabe et al., 1994). Although, certain pesticides are beneficial in controlling disease vectors in agriculture but their main drawback is potential toxicity to other non-target species including man, fish and other aquatic fauna (Gilden et al., 2010). These pesticides easily find their way into the aquatic environment through leaching and contaminate the ground as well as surface water (Mahboob et al., 2011). The long term use of these pesticides can cause their bio-magnification in the environment with detrimental effects based on concentration (Akhter etal., 2014).

Fish serve as a bio-indicator of the aquatic environment and study of their blood or serum physiology can be helpful in understanding the effect of pesticides (Sharma and Singh, 2004).

River Sutlej is surrounded by agricultural fields and hence the pesticide usage is on large scale. Besides, BuddahNallah which joins river Sutlej has become a dumping ground for industrial sewage, and thus apprehensions about the contamination of pesticide in fish muscle lead to design the present study. The present study was conducted to assess the impact of pesticide pollution in river Sutlej environment. Analysis of water, sediment, gill and muscle samples was done to detect the level of Persistent Organic Pollutants (POP's).

\section{Materials and Methods}

Sampling sites: The samples were collected from two different sites of the River Sutlej before and after the confluence of polluted tributary (Buddha Nallah).

Collection and sample preparation: For the estimation of pesticide residue, the samples of fish, sediment and water were collected on seasonal basis i.e., pre-monsoon (June), monsoon (July-September) and post-monsoon period (OctoberDecember). Water samples were collected in one litre plastic sampling bottles and sediment samples were collected in zip lock polythene bags. The fishes studied were Catla catla, Cirrihinus mrigala, Cyprinus carpio, Heteropneustes fossils, Aoricthys aor, Aoricthys seenghala and Wallago attu. The samples collected (fish, sediment and water) from the site were brought to the laboratory of the College of Fisheries, Guru Angad Dev Veterinary and Animal Sciences University, Ludhiana, India in ice packed insulated boxes. Water samples were immediately stored at $4^{\circ} \mathrm{C}$ and soil samples were oven dried at $100^{\circ} \mathrm{C}$ for further analysis. The fish samples were stored at $-20^{\circ} \mathrm{C}$ and analysed within $48 \mathrm{hrs}$.

Extraction of residues in Fish: The extraction and cleanup of fish samples were carried out following the method of Tanabe et al. (1994) with slight modifications. The samples were taken out from deep freezer and kept in running water for thawing without direct contact with running water. After thawing, samples were peeled and only edible portion was used for analysis. The whole sample was thoroughly, homogenized and $5 \mathrm{~g}$ of homogenized tissue sample was used for analysis and balance sample was kept in deep freezer. Thoroughly grounded sample was taken in a mortar and $10 \mathrm{~g}$ of anhydrous sodium sulphate was added to combine with water present to disintegrate sample. It was grinded with pestle until sample and sodium sulphate was well mixed. These mixtures were taken on a filter paper to make a thimble. Thimble was kept in soxhlet extraction apparatus. The residue was extracted from the muscle tissue in soxhlet apparatus using 
solvent diethyl ether (DEE) (150 ml) and hexane (50 ml) (3:1). Residues were extracted in the solvent after 8-9 hrs in the soxhlet apparatus. The extract was taken from the soxhlet in a beaker, the solvent was evaporated in a rotatory vaccum evaporator and weight of fat was estimated by taking difference in beaker weight. The contents were reconstituted in $20 \mathrm{ml}$ hexane: DEE (1:1 v/v).

Extraction of residues in water samples: Water samples were extracted as per the standard methodology described by Hernandez et al. (1993) with slight modifications. Water sample was filtered to remove particulate matter and $500 \mathrm{ml}$ of water sample was transferred to one litre separatory funnel. Then $50 \mathrm{~g}$ of $\mathrm{NaCl}$ was added and it was shaken well till sodium chloride was completely dissolved. The residues were extracted thrice with dichloromethane $(50,25,25 \mathrm{ml})$ and then with $100 \mathrm{ml}$ hexane each time shaking vigoursly for $1 \mathrm{~min}$. Organic layers were combined and passed through sodium sulphate on washed glass wool in a funnel. The samples were evaporated completely and residues were taken into $n$-hexane: acetone $(1: 1 \mathrm{v} / \mathrm{v})$ mixture for analysis by $G C$ with $E C D$.

Extraction of residues in sediment samples: The extraction and clean up of sediment samples were carried out following the method of Tanabe et al. (1994). A $5 \mathrm{~g}$ sediment sample was taken in a mortar and $10 \mathrm{~g}$ anhydrous sodium sulphate was added to combine with water present and to disintegrate sample. It was mixed with spatula until sample and sodium sulphate was well mixed. These mixtures were taken on a filter paper and thimble was made. The thimble was kept in soxhlet apparatus. The fat was extracted from the sediment in soxhlet apparatus by using diethyl ether and hexane solvent in 3:1 ratio. Fat was extracted in the solvent after 8-9 hrs in the soxhlet apparatus. The extract was taken from the soxhlet in a beaker and the solvent was evaporated in rotatory vaccum evaporator.

Clean up: A washed cotton swab was placed at the bottom of a glass chromatographic column and it was rinsed with petroleum ether. A $10 \mathrm{~g}$ activated florisil was added in the glass column, which was pre-washed with 10-15 $\mathrm{ml}$ hexane and extract was concentrated by adding $20 \mathrm{ml}$ of DEE and hexane (1:1) and was added to the column. The column was eluted with $80 \mathrm{ml}$ eluting solvent ( $20 \%$ hexane washed water in acetonitrile) for removal of fat. The eluent was collected in separatory funnel containing 100 $\mathrm{ml}$ hexane and $400 \mathrm{ml}$ of hexane washed water. Subsequently, the concentrate hexane layer was cleaned and fractioned with a $12 \mathrm{~g}$ florisil packed glass column. The first eluted fraction with hexane contained PCB's and p, p-DDE, while the second eluted fraction, with $20 \%$ dichloromethane in hexane, comprised of $\mathrm{HCH}$ isomer, $\mathrm{p}, \mathrm{p}$-DDD and p, p-DDT. The elute was concentrated in a rotatory vaccum evaporator to $5 \mathrm{ml}$ and stored in labeled centrifuged test tubes with stopper for analysis by Gas chromatography.

Estimation of residues: In the present study, Gas Chromatography technique was used for the estimation of pesticide residues in all the analyzed samples. The cleaned up extract measuring 1-2 $\mu$ l was injected in GC through auto injector Shimadzu AOC 20i. For auto injections, sample extract and standard solutions were put in glass vials with vapour tight septum caps. GC solutions software on PC was used for integration and computation of signals. Calibration standard curves were created and residues were quantitatively determined by comparison of the retention time and peak/heights of the sample chromatogram with those of standard solutions run under the same operation conditions. In the present study, the concentration of various residues in each sample was reported as $\mathrm{ng} \mathrm{g}^{-1}$ on lipid weight basis. In general, the volume of the sample extracts for injection was so chosen that it gave approximately the same area or that of the same peak height obtained with the standards.

Statistical analysis: The results were subjected to statistical analysis (Two way Analysis of Variance (ANOVA) and Duncan Multiple Range Test) to find out the significant differences in the concentration of pesticide residue in water, sediment, fish tissue and gills. Statistical analysis part was performed on SPSS-16 $(p<0.05)$ and MS-Excel.

\section{Results and Discussion}

The analysis of twelve water samples during premonsoon, monsoon and post-monsoon season indicated the occurrence of PCB-28 (0.55 $\left.\mathrm{ng} \mathrm{ul}^{-1}\right)$ during monsoon season at

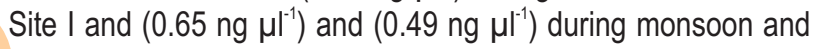
post-monsoon season at Site II. The occurrence of Permithrin at

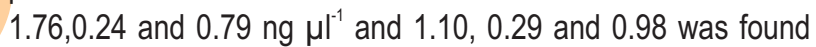
during pre-monsoon, monsoon and post-monsoon period at Site I and Site-2, respectively. The residues of lindane, aldrin, dieldrin, heptachlor, endrin, a -chlordane, p,p'-DDE, methoxychlor, PCB138, PCB-180 were not detected in any of the water sample in this study. Chakraborty et al. (2014) carried a study on the distribution of POP's in surface waters of river Brahamaputra and Ganga ending at Bay of Bengal, and reported the presence of heptachlor, $\mathrm{HCH}$, DDT, dieldrin, aldrin and endosulfan. Persistant organic pollutants are distributed in the waters by various point and nonpoint sources, and hence affect the function of ecosystem and threaten the human health. Besides this the POP's cause endocrine disruptions and bio-magnification in food chain because of their lyophilic property and ability to persist for long time in nature. The results of the present study, with respect to fluctuation in PCBs, indicated the pollution threat posed to the water bodies by rapid industrialization and indiscriminate use of different agrochemicals. Recent studies from Asia have shown that the open municipal dumping sites, common around the outskirts of many metropolitan cities, are a potential emission source of PCBs (Senthil et al., 2001 and Hafeez et al., 2016). Old electrical equipment containing PCBs is believed to be the dominant source of PCB off gassing in urban areas (Breivik et al., 2002). The industrial hub around the river Sutlej could have been 
Table 1 : Seasonal variations of persistent organic pollutants (POPs) $\left(\mathrm{ng} \mu \mathrm{l}^{-1}\right)$ in water at Site I and Site-ll

\begin{tabular}{|c|c|c|c|c|c|c|}
\hline \multirow{2}{*}{$\begin{array}{l}\text { POP's } \\
\text { PCB's }\end{array}$} & \multicolumn{3}{|c|}{ Site1 } & \multicolumn{3}{|c|}{ Site2 } \\
\hline & Pre-monsoon & Monsoon & Post-monsoon & Pre-monsoon & Monsoon & Post-monsoon \\
\hline PCB-28 & ND & $0.55 \pm 0.01^{\mathrm{a}, 2}$ & ND & ND & $0.65 \pm 0.05^{\mathrm{a}, 1}$ & $0.49 \pm 0.03^{\mathrm{b}, 1}$ \\
\hline PCB-138 & ND & ND & ND & ND & ND & ND \\
\hline PCB-180 & ND & ND & ND & ND & ND & ND \\
\hline \multicolumn{7}{|l|}{ OCP's } \\
\hline Permethrin & $1.76 \pm 0.04^{\mathrm{a}, 1}$ & $0.24 \pm 0.05^{\mathrm{c}, 1}$ & $0.79 \pm 0.07^{b, 2}$ & $1.10 \pm 0.07^{\mathrm{a}, 2}$ & $0.29 \pm 0.01^{c, 1}$ & $0.98 \pm 0.01^{\mathrm{b}, 1}$ \\
\hline Fipronil & ND & ND & ND & ND & ND & ND \\
\hline$p, p-D D D$ & ND & ND & ND & ND & ND & ND \\
\hline$p, p-D D E$ & ND & ND & ND & ND & ND & ND \\
\hline
\end{tabular}

${ }^{*}$ ND- Not detected; Note: Values are mean of replicates \pm SD; Superscript $a, b, c \ldots$ shows significant difference within the site during different season and $1,2,3 \ldots$ shows significant difference between the site for particular season

one of the major sources of these pesticides. Earlier studies from India and other countries have reported the occurrence of PCBs residues in aquatic environment (Kannan et al., 2005 and Kuranchie-Menash et al., 2011).

A total of 12 sediment samples were analysed for POPs during the pre-monsoon, monsoon and post-monsoon period out of which only organochlorine pesticide (Fipronil) was detected during the study period. The level of Fipronil was found to be 0.69 $\mathrm{ng} \mathrm{g}^{-1}$ during pre-monsoon season at Site II. The residues of aldrin, dieldrin, heptachlor, endrin, a -chlordane, p,p'-DDE, methoxychlor, PCB-138, PCB-180 were not detected in any of the soil sample during the study. The presence of organochlorine pesticides in the sediment and their mass distribution can be linked to the trophic state of the aquatic ecosystem. According to Kumar et al. (2006) adsorption of isomers of the OCPs ( $\alpha$ and $\beta$ endosulfan) in sandy bottom was insignificant, i.e., the mobility of OCPs is greatest in sandy bottoms and they are retained in consistency in such environments. The absorption of pesticides is directly affected by the composition of organic matter in the environment (Aboul-Kassim et al., 2001). Maurya et al. (2016) in a study recorded around 10 pesticides viz., monochrotophos, parathione, phorete, malathion, $\mathrm{a}-\mathrm{BHC}, \beta-\mathrm{BHC}, \mathrm{\gamma BHC}, \delta-\mathrm{BHC}$, endrine and endosulfon in Cyprinus carpio and Puntius ticto from river Kali. Mondal et al. (2018) studied around 31 pesticide residues in river sediments of Hooghly river basin in West Bengal, and found that about $42 \%$ showed the presence of pesticides and were highest in river sediment as compared to pond and tube well water.

Similarly the analysis of fish gills and muscle tissues revealed some interesting results. For Cirrihinus mrigala, a total of 15 samples of fish flesh were collected and analysed for POPs. During the study among OCP's only p,p'-DDD was detected in the flesh of Cirrhinus mrigala during the pre-monsoon season at Site II at a level of $0.01 \mathrm{ng} \mathrm{g}^{-1}$ while among PCB's only PCB- 28 was detected during pre-monsoon and post monsoon period at Site I $\left(0.26,0.27 \mathrm{ng} \mathrm{g}^{-1}\right)$ and during monsoon $\left(0.17 \mathrm{ng} \mathrm{g}^{-1}\right)$ at Site II (Table 2). In the present study it can be presumed that presence of $p$, p-DDD was due to past exposure to DDT, however, the presence of traces of $p, p^{\prime}-\mathrm{DDD}$ (reduced metabolite of DDT in living beings) can be interpreted as an evidence of low fresh exposure to DDT.

In the gill samples of Aorichthys aor, among PCB's only PCB-28 was detected at Site II during the study period. The level was maximum (0.34 $\left.\mathrm{ng} \mathrm{g}^{-1}\right)$ during pre-monsoon period and minimum $\left(0.19 \mathrm{ng} \mathrm{g}^{-1}\right)$ during monsoon period, respectively (Table 2). Similarly in the gill samples of Heteropneustes fossilis among PCB's, PCB- 28 was detected from Site I $\left(0.26 \mathrm{ng} \mathrm{g}^{-1}\right)$ and Site II during pre-monsoon $\left(0.21 \mathrm{ng} \mathrm{g}^{-1}\right)$ and monsoon period $(0.17 \mathrm{ng} \mathrm{g}$ $\left.{ }^{1}\right)$ while PCB-52 was detected at Site II during pre-monsoon (0.29 $\mathrm{ng} \mathrm{g}^{-1}$ ) and Post-monsoon periods $\left(0.24 \mathrm{ng} \mathrm{g}^{-1}\right)$ (Table 3 ).

In Catla catla gill samples among all PCBs, only PCB-28 was detected at Site II during the study period. The level was maximum $\left(0.32 \mathrm{ng} \mathrm{g}^{-1}\right)$ during pre-monsoon period and minimum $\left(0.24 \mathrm{ng} \mathrm{g}^{-1}\right)$ during post-monsoon period (Table 3). Among OCPs, only mirex $\left(0.01 \mathrm{ng} \mathrm{g}^{-1}\right)$ was detected in the gills of $C$. catla, which may be due to high industrial load that mixes with river water at Site II. Gills are most vulnerable organs to water borne contaminants like pesticides because of their direct exposure. (Mosiichuk et al., 2015). Vivek et al. (2016) in their study found various structural aberrations like fusion of gill lamella, epithelial hyper-plasia, lamellar degeneration etc. in Labeo rohita fingerlings exposed to pesticide. Several other studies have also reported degenerative changes in gills exposed to pesticide (Tabassum et al., 2016). In a recent study, Clasen et al. (2018) studied accumulation of certain pesticides and fungicides in the muscle tissues of Cyprinus carpio reared in a rice fish system after 100 days of exposure, which was followed by oxidative stress and change in the enzymatic activities. Similarly, Varol and Sunbul (2017) found highest concentration of p,p'-DDE (0.032 $\mathrm{mg} \mathrm{kg}^{-1} \mathrm{ww}$ ) in the gills of Cyprinus carpio from the Keban 


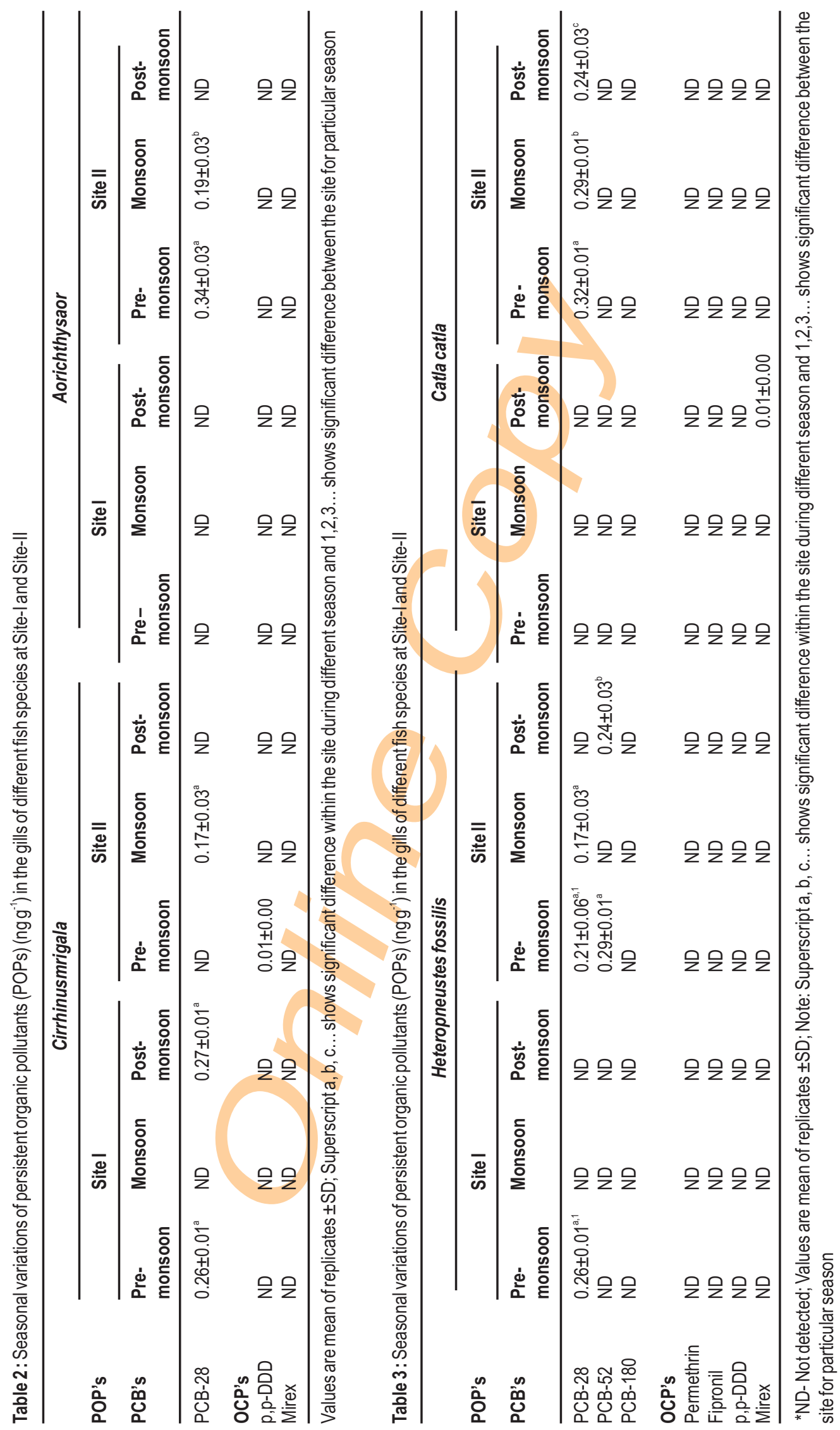


reservoir, Turkey. Swati et al. (2015) reported that river Deomoni in Terai region of West Bengal gets contaminated by pesticides while flowing through tea gardens.

Pesticide accumulation may prompt the activity of several enzymes and metabolites leading to physiological and biochemical changes (Nagarathnamma and Ramamurthi., 1982). Fish gills are also vulnerable to pollutants in water because of their large surface area and external location. Fish gills are considered to be most appropriate indicator of water pollution levels (Alazemi et al., 1996). Nowak (1992) in their study on effects of endosulphan residues on gills of catfish found hyperplasia and lifting of lamellar epithelium. Pfeiffer et al. (1997) also observed secondary distortion and detached pillar cells in Carassius auratus under carbaryl toxicity stress.

The study concludes that all the POP's, detected in water, soil/sediment and selected fish samples were within the maximum permissible limits as prescribed by different agencies but continuous monitoring of pesticide residue is warranted in the river Sutlej to rule out any detrimental effect of pesticide pollution on aquatic fauna. Besides, this awareness should be spread through electronic and print media about the detrimental effects of POP's on aquatic flora and fauna.

\section{Acknowledgments}

The authors are highly thankful to the Dean, College of Fisheries, Guru Angad Dev Veterinary and Animal Sciences University, Ludhiana for providing financial support and laboratory facilities for carrying out this work. The support of Head, Department of Fisheries Resource Management for carrying out this work is duly acknowledged.

\section{References}

Aboul-Kassim, T.A.T. and B.R.T. Simoneit: Interaction mechanisms between organic pollutants ans soil phase systems In: The Handbook of Environmental Chemistry. Springer Verlag, Heidelberg, pp. 107-167 (2001).

Akhter, M., S. Mahboob, S. Sultana,T. Sultana, K.A. Alghanim and Z. Ahmed: Assessment of pesticide residues in flesh of Catla catla from Ravi river, Pakistan. The Sci. World J., 2014, 1-8 (2014).

Alazemi, B.M., W.J. Lewis and E.B. Andrews: Gill damage in fresh water fish, Ganthonemus Ptrisii (Fam: Mormyridae) exposed to selected pollutants, an ultra-structural study. Environ. Technol., 17, 225-238 (1996).

Banee, M., A.R. Mirvagefei., K. Ahmadi and R. Ashori: The effect of Diazinon on histopathological changes of tests and ovaries of Common carp (Cyprinus carpio). Sci. J. Marine Biol., 1, 25-35 (2009).

Brraich, O.S. and S. Jangu: Lepidological and toxicological studies on the scale of a commercially important fish, Cirrhinus mrigala (Hamilton-Buchanan) upon exposure to pollutants in Harike wetland. Trends Fish. Res., 2, 23-29 (2013).

Breivik, K., A. Sweetman., J.M. Pancyna and K.C. Jones: Towards a global historical emission inventory for selected PCB congeners a mass balance approach: Emission Sci. Total Environ., 290, 199224 (2002).

Clasen, B., V.L. Loro, C.R. Murussi, T.L. Tiecher, B. Moraes and R. Zanella: Bioaccumulation and oxidative stress caused by pesticides in Cyprinus carpio reared in a rice fish system. Sci. Total Env., 626,737-743 (2018).

Chakraborty, P., S. Sakthivel, B. Kumar, S. Kumar, M. Mishra, V.K. Verma and R. Gaur: Spatial distribution of persistent organic pollutants in the surface water of River Brahmaputra and River Ganga in India. Rev. Environ Hlth., 29, 45-8 (2014).

Garg, S., R.K. Gupta and K.L. Jain: Sub lethal effects of heavy metals on biochemical composition and their recovery in Indian major carps. J. Haz. Mat., 163, 1369-1384 (2009).

Gilden, R.C., K. Huffling and B. Sattler: Pesticides and health risks. J. Obst. Gyn. Neonatal Nur., 39, 103-110 (2010).

Hafeez, S., A. Mahmood, J.H. Syed, J. Li., U. Ali, R.N. Malik and G. Zhang: Waste dumping sites as a potential source of POPs and associated health risks in perspective of current waste management practices in Lahore city, Pakistan. Sci. Total Environ., 562, 953-961(2016)

Hernandez, J., J. Beltran and J.V. Sancho: Study of multi-residue methods for the determination of selected pesticides in ground water. Sci. Total Environ.,132, 297-312 (1993).

Hynes, H.B.N.: The Biology of Polluted Waters. Liverpool University PUK (1960).

Joseph, B. and S.J. Raj: Impact of pesticide toxicity on selected biomarkers of fishes. Int. J. Zoo. Res., 7, 212-222 (2010).

Kannan, K., K. Ramu, N. Kajiwara, R.K. Sinha and S. Tanabe: Organochlorine pesticides, polychlorinated biphenyls and poly brominated diphenyl ethers in Irrawaddy dolphins from india. Arch. Environ. Contam. Toxi., 49, 415-20. (2005).

Kumar, M. and L. Philip: Adsorbtion and desorption characteristics of hydrophobic pesticide endosulfan in four Indian soils. Chemosphere, 62,1064-1077 (2006).

Kuranchie-Mensah, H., L.M.N. Palm, S.A. Manukure, S. Afful, G. AdjeiMartey and J.K. Arthur: Assessment of organochlorine pesticides and polychlorinated biphenyls levels in fishes from the Volta lake, Ghana and their suitability for human consumption. Elixir Food Sci., 41, 5982-90 (2011).

Mahboob, S., M.R. Assi, F. Niazi, S. Sultana, Ghazala and K.A. AIGhanim: Determination of organochlorine and nitrogen containing pesticide residues in Labeorohita. Tox. Env. Chem. 93,1851-1855 (2011)

Maurya, P.K. and D.S. Malik: Accumulation and distribution of organochlorine and organophosphorus pesticide residues in water, sediments and fishes, Heteropneustis fossilis and Puntius ticto from Kali River, India. J. Tox. Env. Hlth. Sci., 8, 30-40 (2016).

Mondal, R., A. Mukherjee, S. Biswas and R.K. Kole: GC-MS/MS determination and ecological risk assessment of pesticides in aquatic system: A case study in Hooghly River basin in West Bengal, India. Chemosphere, 206, 217-230 (2018).

Mosiichuk, N.M., V.V. Husak, I.V. Maksymiv, O.Y. Hlodan, J.M. Storey, K.B. Storey and V.I. Lushchak: Toxicity of environmental Gesagard to goldfish may be connected with induction of low intensity oxidative stress in concentration-and tissue-related manners. Aquat. Toxicol., 165, 249-258 (2015).

Murthy, K.S., B.R. Kiran and M. Venkateshwarlu: A review on toxicity of pesticides in Fish. Int. J. Open Sci. Res., 1,15-36.(2013).

Nagarathnamma, R. and R. Ramamurthi: Metabolic depression in the 
freshwater teleost Cyprinus carpio exposed to an organophosphate pesticide. Curr. Sci., 51, 668-669 (1982).

Nowak, B.: Histological changes in gills induced by residues of endosulfan. J. Aquat Toxicol., 23, 65-84 (1992).

Ntow, W.J.: Organochlorine pesticides in water, sediment, crops and human fields in a farming community in Ghana. Arch. Env. Con. J., 40, 557-563 (2001)

Pfeiffer, C.J., B. Qiu and C.H. Cho: Electron microscopic perspectives of gill pathology induced by 1 -napthyl- $\mathrm{N}$-methyl carbamate in the gold fish, Carassius auratus (Linnaeus) Histol. Histopathal., 12, 645-653(1997).

Senthilkumar, K., K. Kannan, A. Subramanian and S. Tanabe: Accumulation of organochlorine pesticides and polychlorinated biphenyls in sediment, aquatic organism, birds, bird eggs and bat collected from South India. Environ. Sci. Pollut. Res., 8, 35-47 (2001).

Sethi, P.K. and A.K. Bhattacharya: Current trend of some organochlorinated pesticides in Yamuna river sediments around Delhi. Env. Polu. Control J., 2,40-43 (1999).

Sharma, G. and S. Singh :Studies on the effect of intoxicant indofil on the blood morphology of Channa punctatus (Bloch). Bionotes, 6, 2020 (2004).

Sharma, G. and S. Singh: Effect of indofil toxicity on MCHC of Channa punctatus (Bloch). J. Environ. Res. Dev., 1, 261-263 (2007).

Swati, S., D. Bhutia, S. Sarkar, B.K. Rai, J. Pal, S. Bhattacharjee and M. Bhadur: Analyses of pesticide residues in water, sediment and fish tissue from river Deomoni flowing through the tea gardens of Terai Region of West Bengal, India. Int. J. Fish. Aqua. Stu., 3, 17-23 (2015).

Tabassum, H., M. Ashafaq, J. Khan, M.Z. Shah, S. Raisuddin and S. Parvez: Short term exposure of pendimethalin induces biochemical and histological perturbations in liver, kidney and gill of freshwater fish. Ecol. Indic., 63, 29-36 (2016).

Tanabe, S., J.K. Sung., D.Y. Choi., N. Baba, M. Kiyota, K.Yoshida and R. Tatsukawa: Persistent organochlorine residues in northern fur seal from the Pacific coast of Japan since 1971. Environ. Poll., 85, 30514 (1994).

Varol, M. and M.R. Sunbul: Organochlorine pesticide, antibiotic and heavy metal residues in mussel, cray fish and and fish species from a reservoir on the Euphrates river, Turkey. Env. Pollution., 230,311-319 (2017).

Vivek, Ch., K. Veeraiah, P. Padmavath, H. Dhilleswara and P.V. Bramhachari: Acute toxicity and residue analysis of cartap hydrochloride pesticide: Toxicological implications on the fingerlings of fresh water fish Labeo rohita. Biocata. Agri. Biotec., 7, 193-2016 (2016). 